\title{
Development of A Preparation Scheme for Video Capsule Endoscopy in Children
}

\author{
Evgeniya Kirakosyan ${ }^{1}$ and Maxim Lokhmatov ${ }^{1,2}$ \\ ${ }^{1}$ University of the Ministry of Health of the Russian Federation (Sechenov University), Russia \\ ${ }^{2}$ National Medical Research Center for Children's Health (Scientific Center for Children's Health), Russia
}

Submission: October 14, 2019; Published: November 08, 2019

*Corresponding author: Evgeniya Kirakosyan University of the Ministry of Health of the Russian Federation (Sechenov University), Moscow, Russia

\section{Case Report}

Video capsule endoscopy (VCE) is performed to assess the condition of the deep intestine, if necessary, differential diagnosis in difficult situations or to accurately determine the extent of the lesion. The main purpose of VCE is the diagnosis of pathological changes, localized mainly in the small intestine, in patients with inflammatory bowel diseases, polyposis syndromes, with hidden intestinal bleeding. It should be noted that VCE is an additional research method and is prescribed after EGDS and colonoscopy [1-3]. We have been widely using VCE at the Department of Endoscopic Research of the National Medical Research Center for Children's Health of the Ministry of Health of the Russian Federation since 2003. The investigation is difficult: a large number of artifacts in the visual assessment of the mucous membrane due to spasms and increased gas formation; a delay in the video capsule in the upper digestive tract caused by impaired motility during duodenogastric reflux, as a result of which the video capsule is delayed in the stomach, a part of the battery charge is wasted, the capsule for a long time does not reach the main goal - the deep sections of the digestive tract. Preparing for a video capsule study using enemas or taking laxatives is ineffective, since the promotion of a video capsule through the colon is only possible with feces. To prevent these difficulties, we have developed a preparation scheme for VCE in children [4]. The last meal should be 8-9 hours before the start of the study. 20 minutes before the start of the study a child takes per os 40-80 $\mathrm{mg}$ of an antiflatulence (espumisan=simethicone) once a day, to reduce foaming and improve the quality of the video image. Espumisan (Simethicone) is a drug that reduces gassing in the intestines. This is a surfactant that reduces the surface tension of air bubbles in the gastrointestinal tract, and they disintegrate, resulting in a decrease in the number of artifacts during the study. Available in the form of an emulsion for oral administration in $100 \mathrm{ml}$ vials [4].

Immediately before the start of study, in 1-2 minutes, the child is prescribed a single, oral prokinetics (domperidone=motilium) in a dosage of 10-20mg, which, enhancing the motility of the upper digestive tract, provides faster evacuation of the video capsule from the stomach. Domperidone (Motilium) is an antiemetic drug that increases the duration of peristaltic contractions of the antrum of the stomach and duodenum. The drug accelerates gastric emptying in the event of a slowdown of this process, increases the tone of the lower esophageal sphincter. Available in the form of coated tablets, 10 and 30 tablets per pack, 1 tablet $=10 \mathrm{mg}$; $10 \mathrm{mg}$ lingual tablets, 10 tablets per pack and as a suspension for oral administration $200 \mathrm{ml}$ in a vial, $5 \mathrm{ml}=5 \mathrm{mg}$ [4]. At the same time, domperidone does not affect the deep sections and does not interfere with the assessment of motor function during video capsule research. Thus, the described method of preparing for VCE provides the optimal time for capsule advancement in the upper digestive tract, where the video capsule study does not have high diagnostic value and allows you to focus on endoscopic diagnosis of the deep sections of the small intestine. The use of antiflatulence significantly improves the endoscopic picture and increases the informative value of VCE [5].

At the Battle of the Wilderness General and later President Ulysses Grant said: "William Morton has done more for the soldier than anyone else, soldier or civilian, for he has taught you all to banish pain." What he reached was a true gift to mankind and what he achieved was accomplished at immense personal cost. I picture Dr Morton as a hero in comics, Captain Ether (Figure 1), defeating pain and saving people from the agony of surgery and from those dreadful operations where our patients would feel every nerve severed with each stroke of the knife. Dwarfed the magnitude of his revelation, reviled, hated by his fellow men, forgotten before he was remembered, Morton seems very small indeed until he was immortalized as the founder of painless surgery. The invention of surgical anesthesia was the first major contribution that American medical science made to the world and it is probably still the greatest of America's many medical discoveries. Surgical anesthesia and analgesia have become an accepted standard in medical care. The story of the discovery of 
inhalational anesthesia sounds like a medical melodrama. It is full of comedy, tragedy and intrigue. It is amusing and it sounds so familiar, one can recognize many aspects of it in the hospital dynamics we witness everyday including the interactions among hospital staff colleagues. Some things don't seem to change.

\section{References}

1. Lokhmatov MM, Shcherbakov PL (2006) Evaluation of the effectiveness of intraluminal endoscopy in the diagnosis and treatment of diseases of the digestive system in children. Materials of the X Congress of Pediatricians of Russia p. 340.

This work is licensed under Creative Commons Attribution 4.0 License

DOI: 10.19080/JAICM.2019.09.555774
2. Pennazio M, Spada C, Eliakim R (2015) Small-bowel capsule endoscopy and device-assisted enteroscopy for diagnosis treatment of smallbowel disorders: European Society of Gastrointestinal Endoscopy (ESGE) Clinical Guideline. Endoscopy 47(4): 352-376.

3. Shcherbakov PL, Lokhmatov MM (2005) Videocapsule endoscopy in pediatrics. Program the 4 th International Conference on capsule endoscopy. 153.

4. Spravochnik Vidal (2003) - 2-ye izd. - M. p. 472.

5. Kirakosyan EV, Lokhmatov MM, Dyakonova EY (2019) High-tech diagnostic methods and enteroscopic treatment of children with Peutz-Jeghers syndrome. Rossiyskiy Pediatricheskiy Zhurnal 22(1): $17-22$

Your next submission with Juniper Publishers will reach you the below assets

- Quality Editorial service

- Swift Peer Review

- Reprints availability

- E-prints Service

- Manuscript Podcast for convenient understanding

- Global attainment for your research

- Manuscript accessibility in different formats

( Pdf, E-pub, Full Text, Audio)

- Unceasing customer service

Track the below URL for one-step submission https://juniperpublishers.com/online-submission.php 